УДК 347.238.3(477)

DOI https:// doi.org/10.32837/yuv.v0i5.2014

A. Тарасов,

аспірант кафедри права інтелектуальної власності та патентної юстиції Національного університету «Одеська юридична академія»

\title{
ОБ'ЄДНАННЯ СПІВВЛАСНИКІВ БАГАТОКВАРТИРНИХ БУДИНКІВ: СТАН РЕГУЛЮВАННЯ ТА ПЕРСПЕКТИВИ РОЗВИТКУ ІНСТИТУТУ
}

Постановка проблеми. Житлове питання так чи інакше постає перед кожною особою. Не є новиною, що в сучасних економіко-правових умовах для більшості держав, Україна не виняток, склалася ситуація, за якої «успіх» реалізації права особи на житло $є$ величиною, прямо пропорційною іiі власним зусиллям щодо створення економічних передумов такої реалізації. I хоча окреслений стан проблеми у вітчизняній юридичній практиці більше нагадує всесвітньо відому формулу I. Ільфа і $€$. Петрова про «порятунок потопаючих», у практичній площині діє система інституцій, орієнтованих на забезпечення та захист житлових прав громадян.

Ступінь дослідження проблематики. Діяльність об'єднань співвласників багатоквартирних будинків (далі - ОСББ) привертає увагу багатьох науковців, що пов'язано зі специфікою інституту, а головне, з його функціональною цінністю. Окремі аспекти правової регламентації створення, функціонування та перспектив розвитку ОСББ в Україні вивчені такими дослідниками, як: О. Крупчан, В. Луць, М. Войновський, К. Процак, О. Просович, А. Бабійчук, М. Галянтич, I. Ревуцька й інші. Однак доцільність подальшого наукового дослідження окресленої тематики обгрунтовується низькими показниками поширення створення ОСББ власниками житла, що свідчить про гостру проблематику як у правовому регулюванні, так і в суспільній правосвідомості населення.

Метою статті, 3 огляду на вказане, є висвітлення найбільш проблемних теоретичних аспектів визначення функціональної ролі ОСББ в Україні та проблематики їх діяльності. Необхідним убачається також розкриття основних шляхів реформування нормативно-правової бази, якою регламентуються створення та діяльність ОСББ, теоретичні напрями подальшого наукового опрацювання окремих аспектів їх діяльності.

Виклад основного матеріалу. У логіці вищевказаного варто констатувати той факт, що діяльність згаданих інституцій також стикається із численними перешкодами юридичного характеру, що потребує відповідних законодавчих заходів. У системі правових механізмів забезпечення та захисту житлових прав громадян особливу нішу займають інститути громадянського суспільства, що представлені недержавними установами, громадськими організаціями чи іншими формами об'єднань громадян, діяльність яких спрямована на реалізацію або захист своїх справ, прав третіх осіб, моніторинг дотримання прав громадян юридичними особами, органами державної влади та місцевого самоврядування тощо.

У ст. 36 Конституції України [3] закріплено, серед іншого, право 
громадян України на свободу об'єднання в політичні партії та громадські організації для здійснення і захисту своїх прав і свобод та задоволення політичних, економічних, соціальних, культурних та інших інтересів. У ч. 4 вказаної статті закріплено також заборону примушення до вступу в будь-яке об'єднання громадян чи обмеження громадянина у правах за належність чи неналежність до політичних партій або громадських організацій. Отже, з огляду на проголошений демократичний курс розвитку держави, варто констатувати позитивний тренд правової політики України щодо розвитку громадянського суспільства.

Одним із наявних механізмів забезпечення та захисту житлових прав громадян, а також реалізації принципів громадянської самоорганізації та самоуправління виступають об'єднання співвласників багатоквартирних будинків, діяльність яких урегульовано насамперед Законом України «Про об'єднання співвласників багатоквартирного будинку» від 29 листопада 2001 р. [10]. У ч. 3 ст. 1 вказаного Закону визначено: «Об’єднання співвласників багатоквартирного будинку - юридична особа, створена власниками квартир та/або нежитлових приміщень багатоквартирного будинку для сприяння використанню іхнього власного майна та управління, утримання і використання спільного майна». Відповідно до ч. 1 ст. 4 вказаного Закону, ОСББ створюється для забезпечення і захисту прав співвласників та дотримання іхніх обов'язків, належного утримання та використання спільного майна, забезпечення своєчасного надходження коштів для сплати всіх платежів, передбачених законодавством та статутними документами. Дана позиція доповнюється положеннями ч. 2 вказаної статті, якими ОСББ визначено як непідприємницьке товариство, що створюється для здійснення функцій, визначених законом.
У с. 385 Цивільного кодексу України також визначено, що ОСББ строюється власниками квартир та нежитлових приміщень у багатоквартирному будинку (будинках) для забезпечення експлуатації такого будинку (будинків), користування квартирами та нежитловими приміщеннями й управління, утримання i використання спільного майна багатоквартирного будинку (будинків) [13]. Отже, законодавчо визначена мета ОСББ обгрунтовує функціональне призначення інституту. Відповідно до Закону України «Про особливості здійснення права власності у багатоквартирному будинку», на об'єднання (асоціацію об'єднань співвласників багатоквартирного будинку) може бути покладено частину або всі функції з управління багатоквартирним будинком [11].

Відповідно до ч. ч. 1, 2 ст. 9 Закону України «Про житлово-комунальні послуги» [9], члени правлінь об'єднань співвласників багатоквартирних будинків можуть на громадських засадах залучатися до роботи органів, уповноважених здійснювати контроль за дотриманням стандартів, нормативів, норм, порядків і правил у сфері житлово-комунальних послуг. Із введенням у дію цього Закону в повному обсязі 1 травня 2019 р. втратив чинність Закон України «Про житлово-комунальні послуги» від 24 червня 2004 р. № 1875-IV [8]. Новим Законом упроваджено більш адаптовані механізми регулювання ключових аспектів галузі. Зокрема, як зазначено в листі Міністерства регіонального розвитку, будівництва та житлово-комунального господарства України «Щодо введення в дію з 1 травня 2019 р. Закону України від 9 листопада 2017 р. № 2189-VIII «Про житлово-комунальні послуги»» від 2 травня 2019 р. № 7/10, вказаним Законом визначено нову класифікацію житлово-комунальних послуг, нову систему відносин, що виникатимуть у процесі надання та споживання 
цих послуг, передбачено різні моделі договірних відносин у сфері комунальних послуг, а також визначено особливості укладання, зміни і припинення договорів про надання комунальних послуг у багатоквартирному будинку, змінено підходи до формування тарифів на комунальні послуги та нарахування плати споживачам, запроваджено відповідальність за неналежне виконання договору як для виконавців комунальних послуг, так і для споживачів цих послуг [14].

ОСББ розглядається і як механізм виконання власником свого обов'язку та забезпечення інтересу щодо належного утримання житла, а також як механізм задоволення інтересу власника в утриманні його житла в належному стані [7, с. 50]. Такий підхід більш розширено розкриває юридичну сутність інституту ОСББ, демонструє багатоаспектність його застосування. Доцільним видається акцент на зобов'язальній частині юридичного змісту правового статусу та функцій ОСББ.

Щодо практичної ролі, стану регулювання інституту, відповідності такого регулювання міжнародним правовим стандартам, а також із питань внутрішньої структури та проблематики діяльності ОСББ існують певні розбіжності на рівні теоретичних підходів науковців. Насамперед варто погодитись із думкою, що натепер ОСББ - це відомий і ефективний, хоча й обмежено поширений, інститут, за допомогою якого населення бере участь у здійсненні місцевого самоврядування [2, с. 274].

Створення та функціонування ОСББ має відповідати не лише правовим приписам, але й загальним принципам демократичного суспільства, що передусім проявляється у відповідності їньої діяльності інтересам власників квартир та/або нежитлових приміщень багатоквартирного будинку. Показовим є підхід, відповідно до якого ще на етапі заснування ОСББ виокремлюють такі стадії, як:
1. Переконання співвласників будинку в необхідності створення ОСББ як органу для ухвалення колективних легітимних рішень (оскільки це дозволить управляти спільною неподільною власністю в багатоквартирному будинку, розпоряджатись під’іздами, підвалами й іншими комунікаціями будинку).

2. Скликання та проведення установчих зборів та голосування щодо створення ОСББ.

3. Оформлення всіх необхідних документів для реєстрації ОСББ як юридичної особи [5].

Оподаткування об'єднання співвласників багатоквартирного будинку, асоціації власників жилих будинків відбувається 3 урахуванням віднесення ОСББ і асоціацій до неприбуткових організацій, що відповідають вимогам цього пункту і не $є$ платниками податку. Дане положення встановлено п. 133.4.6 ст. 133 Податкового кодексу України [6]. Зауважимо, що питання правового статусу ОСББ нерідко постає саме в контексті регулювання схем їх оподаткування.

Перспективи розвитку розглядуваного інституту виражаються, на думку автора, у відчутних зрушеннях законодавчої бази, які відбуваються у фарватері загальної тенденції євроатлантичного курсу України. Дехто 3 науковців зазначає, що ОСББ фактично розвивається на перетині двох реформ - муніципальної та житлово-комунальної [2, с. 274]. Деякими вченими пасивна поведінка, небажання мешканців брати на себе відповідальність та брати участь в утриманні власного житла сприймаються як найбільша проблема в аспекті функціонування ОСББ [12, с. 149]. Дана позиція справді відображає одну із ключових проблем досліджуваної тематики. Загалом, стан правосвідомості українського суспільства недосконалий, що слугує підгрунтям для численних правопорушень, зокрема й злочинних проявів та інших негативних правових явищ. 
Це стосується і сфери житлових відносин, зокрема регулювання щодо створення та функціонування ОСББ.

Проте вектор зусиль держави в зазначеній сфері не повною мірою збігається з напрямами, що потребують реагування. Законодавцем сьогодні фактично обрано шлях посилення регулювання сфери житлово-комунальних послуг, що простежується в окремих аспектах реформаційних процесів останніх років щодо зазначеної галузі. Зокрема, у п. 4 розд. VI «Прикінцеві та перехідні положення» Закону України «Про житлово-комунальні послуги» було встановлено обов'язок співвласників багатоквартирних будинків незалежно від обраної ними форми управління багатоквартирним будинком не пізніш як 1 травня 2020 р. ухвалити рішення про модель організації договірних відносин із виконавцями комунальних послуг (крім послуг із постачання електричної енергії та природного газу) щодо кожного виду комунальної послуги, а також обов'язок виконавців комунальних послуг укласти 3 такими співвласниками договори про надання відповідних комунальних послуг згідно з обраною співвласниками моделлю організації договірних відносин. Така активність державної політики розцінюється дослідниками по-різному. Зокрема, О. Крупчан i В. Луць констатують активну зацікавленість публічних органів влади у створенні ОСББ як засобу вирішення окремих законодавчих колізій. Однак таку «наполегливість» учені розглядають радше як спробу «перекласти тягар» утримання житлового фонду, що перебуває в незадовільному стані [7, с. 171].

У тім, має місце й інший характер державного стимулювання розвитку інституту ОСББ. Як зазначають окремі правники, стимулювання процесу створення все нових ОСББ відбувається як на державному рівні, так і на місцевих, шляхом затвердження «бонусних» програм, надання різно- манітних пільг та проведення інших заохочувальних заходів. Дана тенденція розглядається як один зі шляхів подолання «радянського спадку», представленого недоглянутими багатоповерхівками як елементом ландшафту кожного міста [1]. Наведена закономірність загалом відповідає сучасному курсу державного будівництва в Україні. Передача водночас повноважень та відповідальності щодо стану власного житла його власнику має сприяти, за умови правового регулювання й економічної підтримки, не лише підтриманню належного стану будинків, але й виведенню на якісно новий рівень правосвідомості кожного індивіда. Однак дані процеси мають підпорядковуватись чітко спланованій та соціально орієнтованій державній політиці розвитку житлового фонду в Україні.

За наявності законодавчих, економічних i організаційних (людський чинник) проблем, можливість ix ефективного подолання розглядається як цілком реальна. Висуваються, зокрема, пропозиції щодо розробок організаційно-економічного забезпечення функціонування асоціацій ОСББ [12, с. 149-150]. В. Коцюк виділив такі умови ефективного функціонування ОСББ, як: 1) законодавча база; 2) навчання, обмін досвідом; 3) підтримка місцевих органів влади; 4) обслуговуючий персонал; 4) приміщення; 5) оргтехніка; 6) інформаційне забезпечення; 7) платоспроможність мешканців [4]. Наведеним визначено ключові аспекти діяльності ОСББ, підвищена увага до яких здатна створити сприятливі умови для вдосконалення регулювання інституту.

Варто зауважити необхідність паралельно сприяти розвитку засобів правового регулювання діяльності управляючих (обслуговуючих) компаній із метою стимулювання ведення ними прозорої та відповідальної діяльності в інтересах співвласників багатоквартирних будинків. Так, необхідне подальше теоретичне 
опрацювання концептуальних шляхів удосконалення інституту ОСББ в Україні, що має включати, серед іншого, такі напрями, як: узгодження національного поточного законодавства 3 установленими конституційними вимогами та міжнародними стандартами, вивчення закордонного досвіду функціонування громадянських інститутів щодо забезпечення та захисту житлових прав, моніторинг та реформування механізмів контролю за дотриманням житлових прав співвласників багатоквартирних будинків.

Висновки. Особлива увага науковців до ОСББ як суб'єкта права пояснюється вагомою роллю даного інституту в забезпеченні, реалізаціі та захисті житлових прав громадян. Сучасний стан дослідженості зазначеного інституту характеризується, з одного боку, наявністю численних науково-теоретичних напрацювань та розробок учених, а також позицій судових та інших органів держави, 3 іншого - відчутною необхідністю подальшого наукового опрацювання тематики в контексті вдосконалення функціонування ОСББ в Україні відповідно до міжнародних юридичних стандартів та імплементованих принципів забезпечення та захисту житлових прав людини.

Механізми, що забезпечують житлові права особи, діють у контексті проголошених прав людини, потребують подальшого наукового аналізу, результатом якого має стати більш ретельне усвідомлення функціональної природи ОСББ і вдосконалення державно-правового регулювання інституту. Загальний аналіз інституту ОСББ у його сучасному становищі висвітлює широке коло проблемних аспектів, кожен з яких потребує фокусованого дослідження.

Подальших розробок потребують питання щодо: збільшення присутності держави в економічному та правовому забезпеченні діяльності ОСББ, захисті прав та інтересів учасників
ОСББ; дослідження та впровадження закордонного досвіду об'єднань громадян у сфері захисту житлових прав; регулювання діяльності управляючих (обслуговуючих) компаній і алгоритмів їх обрання.

У статті досліджено сучасний стан правового регулювання діяльності об'єднань співвласників багатоквартирних будинків в Україні. Наведено нормативно-правове та теоретичне обтрунтування інстиmуту об'єднань співвласників багатоквартирних будинків. Проведено порівняльний аналіз концепцій подальшого інституизйного розвитку об'єднань співвласників багатоквартирних будинків в Україні та вирішення проблематики ї нормативно-правового регулювання. Виведено найбільи проблемні теоретичні аспекти визначення функціональної ролі об'єднань співвласників багатоквартирних будинків в Україні, їньої діяльності. Запропоновано основні напрями реформування нормативно-правової бази, якою ретламентуються створення mа діяльність об'єднань співвласників багатоквартирних будинків, а також теоретичні напрями подальшого наукового опрацуювання окремих аспектів їхьої діяльності. Запропоновано подальше опрацювання збільшення присутності держави в економічному та правовому забезпеченні діяльності об’єднань співвласників багатоквартирних будинків, захисті прав та інтересів учасників об'єднань співвласників багатоквартирних будинків; дослідження та впровадження закордонного досвіду об'єднань громадян у сфері захисту житлових прав; регулювання діяльності управляючих (обслуговуючих) компаній, алгоритмів їх обрання. Доводиться необхідність поглибленого дослідження та застосування закордонного досвіду регулювання об'єднань громадян у сфері захисту 
житлових прав. Розглянуто проблематику регулювання діяльності управляючих (обслуговуючих) компаній $i$ алгоритмів їх обрання. Акиентовано увагу на питанні усвідомлення функціональної природи об'єднань співвласників багатоквартирних будинків иляхом ї дослідження в контексті системи прав людини та громадянина. Визначено необхідність подальшого наукового аналізу з метою вдосконалення державно-правового регулювання інституту об'єднань співвласників багатоквартирних будинків в Україні.

Ключові слова: об'єднання співвласників багатоквартирних будинків (ОСББ), асоціації, функції ОСББ, умови розвитку.

\section{Tarasov A. Apartment building co-owners association: state of regulation and development prospects}

The article examines the current state of legal regulation of the activities of apartment building co-owners association in Ukraine. The normative-legal and theoretical substantiation of the ABCA institute is presented. A comparative analysis of the concepts of further institutional development of condominiums in Ukraine and the solution of the problems of its legal regulation is carried out. The most problematic theoretical aspects of defining the functional role of condominiums in Ukraine and the problems of their activities are presented. The main directions of reforming the regulatory framework, which regulates the creation and activities of condominiums, as well as theoretical directions for further scientific study of certain aspects of their activities are proposed. It is proposed: further processing of the increase in the state's presence in the economic and legal support of the activities of condominiums, protection of the rights and interests of condominium participants; research and implementation of foreign experience of associations of citizens in the field of protection of housing rights; improvement of regulation of the activities of management (service) companies and algorithms for their election. The need for an in-depth study and application of foreign experience in regulating citizens' associations in the field of protecting housing rights has been proved. The article considers the problems of regulating the activities of management (service) companies and algorithms for their election. The attention is focused on the issue of realizing the functional nature of associations of co-owners of apartment buildings through its research in the context of the system of human and citizen rights. The need for further scientific analysis in order to improve the state and legal regulation of the institution of $A B C A$ in Ukraine is determined.

Key words: apartment building co-owners association (condominiums), associations, ABCA functions, development conditions.

\section{Література}

1. Бабійчук А. Право власності на cпiльне майно в ОСББ. URL: https:// dominanta.od.ua/publikacia/pravo_ vlasnosti_na_spilne_maino_v_osbb/.

2. Войновський М. Об'єднання співвласників багатоквартирного будинку у системі місиевого самоврядування. Ефективність державного управління. 2015. Bun. № 45. C. 274-284.

3. Конституиія України: Закон України від 28 червня 1996 р. URL: https: / / zakon.rada.gov.ua/laws / show / $254 \%$ D0\% BA / $96-\%$ D0\% B2\% D1\% 80 ? find $=1$ \& text $=\%$ D $1 \% 94 \%$ D $\% \%$ B2\% D1 $\% 80 \# w 1 \_1$.

4. Об'еднання співвласників багатоквартирного будинку: практичні поради : практичний посібник. Львів, 2011. 128 с. URL: http://wrw.urban-project.lviv.ua/ php_uploads / data / articles / ArticleFiles_32_ OSBB_2_book.pdf. 
5. Переваги створення об'єднання співвласників багатоквартирного будинку (OCББ). URL: https: / / honcharukpartners. com/perevagi-stvorennya-obyednannyaspivvlasnikiv-bagatokvartirnogo-budinkuosbb/.

6. Податковий кодекс України від 2 грудня 2010 р. № 2755-VI. URL: https: / / zakon.rada.gov.ua/laws/show / 2755-17.

7. Право власності на житло в Україні : доктрина та реалізація : монографія / за заг. ред. О. Крупчана, В. Луияя. Київ : Науково-дослідний інститут приватного права $і$ підприємництва імені академіка Ф.Г. Бурчака НАПрН України, 2016. 247 c

8. Прожитлово-комунальніпослуги:Закон України від 24 червня 2004 р. № 1875-IV. URL: https://ips.ligazakon.net/document/ t041875? an $=\& e d=\& d t m=\& l e=$.

9. Про житлово-комунальні послуги : Закон України від 9 листопада 2017 р. № 2189-VIII.URL:https: / / zakon.rada.gov.ua/ laws / show $/ 1875-15$ ? find $=1$ \& text $=\% D 0 \% B E$ $\%$ D0\% B1\% $27 \%$ D1\% $94 \%$ D0\% B4\% D0\% BD $\%$ D0\% B0\% D0\% BD\#w1_1.

10. Про об'єднання співвласників багатоквартирного будинку : Закон України від 29 листопада 2001 р. № 2866-III.
URL: https: / / zakon.rada.gov.ua/laws/ show / 2866-14\#Text.

11. Про особливості здійснення права власності у багатоквартирному будинку : Закон України від 14 травня 2015 p. № 417-VIII. URL: https:// zakon.rada.gov.ua/laws / show / 417-19? fin $d=1$ \&text $=\%$ D0\% BE $\%$ D0\% B1\% $27 \% \mathrm{D} 1 \%$ $94 \%$ D0\% B $4 \%$ DO $\%$ BD $0 \%$ DO BO $D 0 \%$ B D\#w1_1.

12. Процак К., Просович О. Сучасні проблеми функціонування об'єднань співвласників багатоквартирних будинків. Вісник Національного університету «Львівська політехніка». 2016. Bun. 3. C. 145-150.

13. Цивільний кодекс України : Закон України в ред. від 16 липня 2020 р. URL: https: / / zakon.rada.gov.ua/laws / show/435-15\#Text.

14. Щодо введення в дію з 1 травня 2019 р. Закону України від 9 листопада 2017 р. № 2189-VIII «Про житлово-комунальні послуги» : лист Міністерства регіонального розвитку, будівництва та житлово-комунального господарства України від 2 травня 2019 р. № $7 / 10.1 / 7260-19$. 